\title{
Järjestökoulutus kestävän elämän tukijana
}

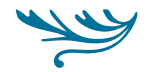

Kestävyyskysymykset ovat kansalaisjärjestöille yhä tärkeämpiä. Sivistyminen kestävään elämään on niille ennen kaikkea tiedon asia. Näin osoittaa analyysi Opintokeskus Siviksen jäsenjärjestöjen koulutuksesta. Tiedon rinnalle tarvitaan toimintaa.
\end{abstract}

EUROOPAN AIKUISKOULUTUSJÄRJESTÖ (EAEA) nimesi vuonna 2015 julistuksessaan aikuiskoulutuksen yhdeksi tehtäväksi ympäristöajattelun vahvistamisen ja kestävän kehityksen periaatteiden toteutumisen. Vuonna 2016 Euroopan unionin yhteisessä näkemyksessä kestävästä kehityksestä kansalaisjärjestöille haluttiin aiempaa paremmat mahdollisuudet osallistua kestävän kehityksen prosessiin poliittisissa, yhteiskunnallisissa ja taloudellisissa vuoropuheluissa. (Euroopan komissio 2016; EAEA 2016.)

Covid-19-pandemia on nostanut kestävän kehityksen välittömän tarpeellisuuden esille ja osoittanut, kuinka haavoittuvainen maapallon ekosysteemi on. Nostetta ovat saaneet niin tietoisuus hyvinvoinnista ja terveydestä kuin tahtotila kestävään elämänmuutokseen. Esimerkiksi käsitöiden ja leipomisen merkityksellisyys kokemuksellisena oppimisena on lisääntynyt, samoin lähimmäisten tuen arvostus, oman hyvinvoinnin merkitys ja kaipuu luontoon.
Kansalaisjärjestöt ovat yhteisöjä, joissa merkityksellisyyden kokemuksen voi jakaa. Muutkin kuin ympäristöjärjestöt auttavat kestävän kehityksen tietouden levittämisessä, taitojen opettamisessa ja ajattelutapojen muokkaamisessa. Ne rakentavat kestävää elämää edistävää sivistystä, joka on hyväntahtoisuutta ja avarakatseisuutta ja jolla rakennetaan luottamusta ja ylitetään olemassa olevaa (Joutsenvirta \& Salonen 2020). Kansalaisjärjestöjen rooli demokratian edistäjinä, sosiaalisen oikeudenmukaisuuden ja ihmisoikeuksien puolustajina (Euroopan komissio 2016) tekee niistä tärkeitä kestävän elämän lähettiläitä.

Minkälaista kestävän kehityksen koulutusta ja oppimista kansalaisjärjestöt sitten tuottavat? Opintokeskus Sivis tarkasteli jäsenjärjestöjensä vuonna 2018 toteuttamaa yli 5000 opintojaksoa ja etsi niistä vastauksia kestävän kehityksen näkyvyyteen järjestökoulutuksissa. Lisäksi se keräsi kesällä 2020 
yhdessä Suomen itsenäisyyden juhlarahaston Sitran Sivistys+-ohjelman kanssa järjestöiltä kysely- ja ryhmähaastatteluaineiston.

Ryhmähaastattelulla täsmennettiin ja syvennettiin kyselyn teemoja. Siihen osallistuivat Siviksen neljän jäsenjärjestön koulutuksesta vastaavat henkilöt. Haastateltavat valittiin järjestöistä, joissa oli Sivisverkon kestävää elämää koskevaa koulutusta, mutta joiden oma toimiala oli muu kuin ympäristöala. Sivis kartoittaa järjestöiden kestävää elämää lisäksi kahden - kolmen vuoden välein osaamistarvekyselyssä, joista tuorein on vuodelta 2020.

Tekstimme syntyi tarpeesta ymmärtää, mitä kestävä kehitys on järjestökoulutuksissa sekä millaisia tietoja ja taitoja oman toiminnan kautta omaksutaan. Keskeiseksi kysymykseksi nousi tiedon, oppimisen ja toiminnan välinen yhteys, jota pohdimme hyödyntäen transformatiivisen oppimisen (esim. Mezirow 1997) teoriaa.

\section{TARVETTA SIVISTYSKÄSITYKSEN UUDISTAMISELLE}

Yhdistyneiden kansakuntien (YK) jäsenmaiden vuonna 2015 sopima kestävän kehityksen Agenda 2030 -toimintaohjelma antaa muutostavoitteita kohti kestävää kehitystä. Se sisältää 17 tavoitetta ja 169 alatavoitetta sosiaalisen oikeudenmukaisuuden, ympäristön tilan ja talouden kestävyyden parantamiseksi. Kuluvana vuonna 2021, kun määräaikaan on kymmenisen vuotta, toimintaohjelman on todettu etenevän kohti tavoitteitaan liian hitaasti, ja tarvitaan toimien kiihdyttämistä ja yhä kokonaisvaltaisempia muutoksia (Global Sustainable Development Report 2019; Dufva 2020; Kestävyyspaneeli 2020). YK:n asettaman itsenäisen kansainvälisen tutkimusryhmän Global Sustainable Development Report-raportissa todetaan, että toimintaohjelman tavoitteiden toteutuminen on vaarassa erityisesti, koska niitä tarkastellaan toisistaan irrallisina.

Kestävän kehityksen ja ilmastotyön kiireellisyys haastaa käsityksemme sivistyksestä ja oppimisesta. Sivistyskäsitykseen on tullut aiempaa vahvemmin ekologisuuden ja sosiaalisuuden yhdistävä ulottuvuus, joka rakentuu yksilön inhimillisestä kasvusta, luonnon ja toisten ihmisten ymmärtämisestä sekä kaiken elämän arvokkaana pitämisestä. Sivistymisessä tunnistetaan ekologisen, sosiaalisen ja taloudellisen todellisuuden välisiä keskinäisriippuvuuksia. (Foster, Salonen \& Keto 2019; Joutsenvirta \& Salonen 2020.) Koska asia on monitahoinen ja vaikeasti hahmotettava, käytämme 'kestävän elämän' käsitettä, jonka avulla tarkastelemme sosiaalisesti, taloudellisesti ja ekologisesti kestävää yhteiskuntaa, hyvinvointia ja sivistymistä.

Kun kestävä elämä yhdistetään aikuisoppimiseen, nostetaan usein esiin transformatiivinen oppiminen. Siinä yksilö kyseenalaistaa kriittisen ajattelun avulla omaa toimintaansa sekä oppii muuttamaan ennakko-oletuksiaan ja tulkintaansa maailmasta. Sosiologi Jack Mezirovin (1997) teoriaan perustuvassa oppimiskäsityksessä itsenäinen ajattelu nähdään olennaisena, jotta yksilö voi elää demokratiassa ja tehdä muuttuvassa maailmassa moraalisesti oikeita päätöksiä. Transformaatio ei välttämättä suuntaudu tiettyyn kohteeseen ja muutu toiminnaksi, joten sitä ei koeta kestävän elämän opetuksen ja oppimisen näkökulmasta riittäväksi. Sen rinnalle on nostettu muun muassa yhteiskuntafilosofi Paolo Freiren ajatteluun nojaava sosio-emansipatorinen oppiminen, joka sisältää myös voimaantumisen ja toiminnan ulottuvuuden (Laininen 2018; Taylor 2008).

Järjestöissä oppiminen tähtää usein yhteisölliseen toimintaan. Silti kestävän elämäntavan omaksuminen saattaa jäädä järjestötoiminnassa vaillinaiseksi. Ympäristötutkijat Nina Lansbury Hall ja Ros Taplin (2007) ovat havainneet, että australialaisten ympäristöjärjestöjen kampanjoinnissa koulutuksellisuus on enemmän viestintää ja tietoisuuden herättämistä kuin varsinaista oppimista tukevaa toimintaa. Kansalaisjärjestöt pyrkivät ilmastoaiheilla usein siihen, että tietoisuus kasvaa, jolloin kansalaiset osaavat vaatia päättäjiltä ilmastotoimia. Tietoisuudesta ei välttämättä kuitenkaan seuraa toimintaa. (Hall \& Taplin 2007.)

\section{AINEISTONA OPINTOKESKUKSEN JÄRJESTÖKOULUTUS}

Ensisijainen aineistomme on tiedot Opintokeskus Siviksen tukemista opintojaksoista vuonna 2018. Sivis on yksi Suomen 12 opintokeskuksesta, jotka järjestävät opintoja vapaan sivistystyön oppilaitoksina 


\section{J ̈̈RJESTÖKOULUTUSTEN}

\section{EDIST $\ddot{A M A ̈ ~ K E S T ~} \ddot{A} V \ddot{A}$ \\ EL $\ddot{M} \ddot{A}$ TOTEUTUI ETENKIN}

\section{KURSSEINA RUOKATALOUDEN}

\section{EKOLOGISUUDESTA.}

yhdessä jäsenjärjestöjensä kanssa. Kestävän kehityksen edistäminen sekä aktiivinen kansalaisuus ja hyvinvointi sisältyvät vapaan sivistystyön lakiin (632/1998). Vuonna 2018 Siviksellä oli 71 jäsenjärjestöä, jotka lukeutuivat kansanterveys- ja vammaisjärjestöihin, kasvatus- ja kulttuurijärjestöihin, erityisjärjestöihin sekä neuvonta-, luonto ja ympäristöjärjestöihin. Ne toteuttivat kursseja yhteiskunnasta, järjestötoiminnasta, kulttuurista, luonnosta ja ympäristöstä, matkailusta, ravitsemuksesta ja taloudesta, kasvatuksesta, pelastuksesta ja turvallisuudesta sekä tekniikasta ja liikenteestä.

Kullakin kurssilla oli vastuullinen toteuttajansa, kouluttajansa ja oppimistavoitteensa. Aineistona olevat opintojaksot eli kurssit on tuotettu analysoitavaksi Siviksen sähköisestä koulutuksen ohjausjärjestelmästä, Sivisverkosta. Aineisto sisältää tiedot jokaisesta vuonna 2018 toteutuneesta kurssisuunnitelmasta, johon oli kirjattu toteuttaja, kurssin esittely, oppimistavoitteet, aiheluokka, aihe sekä ohjelma. Analysoitavia opintojaksoja oli 5272 . Lisäksi pohdintoja täydennettiin havainnoilla keräämästämme kysely- ja ryhmähaastatteluaineistosta ja vuoden 2020 osaamistarvekyselyn tuloksilla.

Lähestyimme Sivisverkon kurssiaineistoa laadullisesti pohtimalla, minkälaisista aiheista kansalaisjärjestöt kouluttavat sekä miten sisällöt ja aiheet kytkeytyvät kestävään kehitykseen. Aineistosta etsittiin luennan avulla kursseja, jotka sisälsivät Agenda 2030 -toimintaohjelman mukaisia tavoitteita. Tarkastelu rajattiin tietoisesti agendan tavoitteisiin, sillä laajasti ajateltuna mikä tahansa järjestökoulutus voidaan lukea kestävään kehitykseen.

Analysointi alkoi luennalla, josta syvennettiin koulutusten sisältöihin, aiheisiin, ohjelmiin ja vielä lähemmin osaamistavoitteisiin. Merkitsimme aineis- toon kaikki koulutukset, joiden sisällöissä esiintyi agendan mukaisia tavoitteita: 71 jäsenjärjestöstä niitä oli 33 jäsenjärjestöllä ja 349 koulutuksessa. Seuraavaksi keräsimme merkityt koulutukset yhteen ja luokittelimme ne sisältöjen mukaisiksi kokonaisuuksiksi. Tämän jälkeen jaottelimme aiemman luokittelun pohjalta syntyneet kokonaisuudet agendan mukaisiin tavoitteisiin. Merkitseminen helpotti aineiston käsiteltävyyttä, ja luokittelu jäsensi sitä yhä analysoitavampaan muotoon (ks. Eskola \& Suoranta 2000).

Agenda 2030 -tavoitteita aineistossa olivat
1) ei köyhyyttä
3) terveyttä ja hyvinvointia
4) hyvä koulutus
7) edullinen ja puhdas energia
10) eriarvoisuuden vähentäminen
12) vastuullinen kuluttaminen
13) ilmastotekoja
14) vedenalainen elämä
15) maanpäällinen elämä
16) rauha ja oikeudenmukaisuus.

Parhaiten järjestökoulutusten edistämä kestävä elämä vastasi agendan tavoitteeseen vastuullisesta kuluttamisesta ruokatalouden ekologisuutena, josta oli 79 kurssia, sekä kiertotaloutena, josta kursseja oli 41. Köyhyyden poistaminen oli esillä sosiaaliturvan muodossa 58 kurssilla. Terveyden ja hyvinvoinnin lisääminen näkyi ehkäisevänä päihdetyönä 28 kurssilla. Tavoite hyvästä koulutuksesta sisältyi 64 perustaitokurssiin. Eriarvoisuuden vähentämisen tavoitetta tuettiin ystävätoiminnan muodossa 43 kurssilla. Jäljelle jääviä viittä tavoitetta opetettiin jokaista keskimäärin alle 10 kurssin sisällöissä.

\section{EKOLOGINEN AJATTELU UUDISTUU}

Minkälaista oppimista kestävään elämään kasvattava järjestökoulutus tuottaa erityisesti transformaation näkökulmasta? Toimintaohjelman tavoite vastuullisesta kuluttamisesta tavoittelee luonnonvarojen kestävää käyttöä, ruokahävikin ja jätteiden syntymisen vähentämistä sekä tietoutta kestävästä kehityksestä ja luontoa suosivista elämäntavoista (UNSD 2017). 
Koska ruokahävikin vähentäminen on helpoin ja nopein tapa parantaa ravinnon tuotannon ja kulutuksen kestävyyttä (Kestävyyspaneeli 2020), vastuullista kuluttamista kuvattiin osaamistavoitteissa ”tietouden kasvattamiseksi ruoan ympäristövaikutuksista” ja ruokahävikin poistamiseksi. Osallistujan kuvattiin esimerkiksi ymmärtävän kasvisten merkitys osana terveellistä ja monipuolista ruokavaliota, tuntevan lihan korvikkeena käytettäviä proteiinipitoisia ruoka-aineita ja oppivan tekemään hyvää kasvisruokaa. Tavoitteet olivat tiedollisia, kuten osallistujien ohjaamista kohti kestävämpiä kulutusvalintoja, sekä tiedon lisäämistä ruoan ympäristövaikutuksista, ruokajärjestelmän haavoittuvuudesta ja omavaraisuudesta. Aineistosta erottui myös ilmastotekojen tavoite yksittäisillä kursseilla proteiinikorvikkeista ja ruokaturvasta.

Kansalaisjärjestöt tekevät aineiston perusteella osansa tavoitteesta opastaessaan osallistujia vastuulliseen ruoan kuluttamiseen ja luodessaan heille mahdollisuuksia ymmärtää yhä paremmin ruoantuotantoa sekä kehittyä yhä vastuullisemmiksi kuluttajiksi. Toiminnallisuutta kursseille tuo esimerkiksi ruoanlaitto: opittuaan valmistamaan maistuvaa kasvisruokaa opiskelijat oletetusti valitsevat ruokaostoksilla ilmastoystävällisiä kasvistuotteita, kun heidän mahdolliset ennakkokäsityksensä kasvisruoasta on haastettu. Kuluttajina he osaavat pyytää kasvisvaihtoehtoja kauppojen hyllyille. Jos oppiminen olisi näin suoraviivaista, se noudattaisi käsitystä transformaatiosta ja emansipaatiosta, mutta kurssikuvauksista muutosta ei voi päätellä.

Yhteisöt ja yksilöt voivat vaikuttaa kestävyyden saavuttamiseen myös siirtymällä kiertotalouteen (Kestävyyspaneeli 2020). Kursseilla esimerkiksi koulutettiin kiertotaloudesta kertovia vierailijoita kouluihin. Osaamistavoitteena oli "ymmärtää kestävän kehityksen ja kiertotalouden perusperiaatteita sekä osata soveltaa niitä arjen valintoihin”. Entisöintija korukursseilla annettiin puolestaan mahdollisuus kunnostaa ja käyttää uudestaan esineitä. Samalla oli mahdollista oppia hyödyntämään kierrätysmateriaaleja monipuolisesti, kuten ”oppimalla kunnostamaan ja entisöimään huonekaluja erilaisilla pintakäsittelyillä, liimauksilla ja puu- ja viilupinnan korjaustavoilla”.
Agendan tavoitteita merien, vesistöjen ja maaekosysteemien suojelusta, maaperän köyhtymisen pysäyttämisestä ja luonnon monimuotoisuuden häviämisestä edistettiin kursseilla, joilla harjoiteltiin ympäristöonnettomuuksien torjuntaa. Vesistöjen hoito, suoekologia, metsien suojelu ja luomuviljely huomioitiin yksittäisillä kursseilla.

Sivisverkon aineistossa oli lisäksi kursseja, joiden oppimistavoite keskittyi ekologiseen energian ja veden kulutukseen, asumisen ja liikkumisen ympäristövaikutuksiin, jätehuoltoon, uusiin energiamuotoihin ja energiatehokkaisiin ruoanvalmistusmenetelmiin. Esimerkit energiankäytöstä kuvastavat järjestöjen tapaa tehdä riippuvuussuhteita näkyviksi, avartaa ajattelutapaamme ja kannustaa osallisuuteen. Joillakin kursseilla kuitenkin opiskellaan muunlaista aihetta, kuten pelastustoimintaa, jolloin kestävään elämään liittyvä transformaatio tapahtuu vaivihkaa.

\section{YHTEINEN HYVINVOINTI}

Kansanterveys- ja vammaisjärjestöjen tuottamat kurssit sosiaaliturvajärjestelmästä sijoittuvat agendan tavoitteisiin köyhyyden torjunnasta, terveydestä ja hyvinvoinnista sekä eriarvoisuuden vähentämisestä. Kestävän elämän sosiaalinen ulottuvuus painottui aineistoissa osittain siksi, että mukana oli runsaasti sosiaali- ja terveysjärjestöjä. Koulutuksilla tuettiin esimerkiksi omaishoitajia, sairastuneita, vammautuneita perheineen hakemaan tietoa oikeuksista, sosiaaliturvajärjestelmästä ja yhteiskunnan tukimuodoista sekä asumisen ja liikkumisen tukipalveluista. Tavoitteina olivat toimintakyvyn ylläpito, kuntoutus, tietous ja ymmärrys sairaudesta ja sen ennaltaehkäisystä sekä vertaistuen mahdollistaminen. Ilmastonmuutoksen vaikutusten onkin todettu kohdistuvan erityisesti terveyteen ja hyvinvointiin, sillä köyhät ja esimerkiksi pitkäaikaissairaat, iäkkäät ja lapset ovat niiden suhteen haavoittuvaisia (ks. Peltosalmi ym. 2020). Hyvinvoinnin ja terveyden tavoite sisältää myös päihteiden väärinkäytön ehkäisemisen ja hoidon (UNSD 2017). Aihetta käsiteltiin kursseilla puheeksi ottamisena ja huolen ilmaisuna sekä varhaisena puuttumisena ja vaikutusten arviointina. 


\section{ERIARVOISUUDEN}

\section{VÄHENTÄMINEN EDIST T̈̈̈}

\author{
SAMALLA RAUHAA JA \\ OIKEUDENMUKAISUUTTA.
}

Hyvinvointia kannattelee lisäksi agendan tavoite hyvästä koulutuksesta. Se luo arvoja ja käytäntöjä, jotka tukevat kestävää kehitystä sekä tarttuvat eriarvoisuuden ehkäisemiseen vahvistamalla perustaitoja sekä kestävän kehityksen edistämisessä tarvittavia tietoja ja taitoja. Aineistoon sisältyi muutamia kerho- ja luontoleiriohjaajakursseja, joiden tavoitteena oli, että osallistujat oppisivat ympäristökasvatusta sekä ympäristöongelmista puhumista lapsille.

Perustaitopuutteet toiminnallisessa lukutaidossa ovat merkityksellisiä, kun informaatiosta tulisi osata tunnistaa väärä tieto ja oppia lisää kestävän elämän ilmiöstä. Eniten perustaitojen koulutusta annettiin digitaidoista, joita opetettiin järjestötoimijoille ja esimerkiksi iäkkäille tarjoamalla käytännön harjoitusta älylaitteiden käyttöön. Tuki järjestötyöntekijöille oli työssä tarvittavien sovellusten harjoittelua. Digitaitojen on ajateltu takaavan osallistumisen yhteiskunnassa, ja niiden kouluttaminen onkin tärkeää, jotta kukaan ei olisi taidonpuutteen takia syrjäytymisvaarassa (EAEA 2016).

Useat kurssisisällöt tukevat aktiivista kansalaisuutta, jonka edellytys transformaatio on (Mezirow 1997). Transformaation lisäksi emansipaatio ja muutos vaativat minäpystyvyyttä eli myönteistä käsitystä omista kyvyistä. Sitä rakentaa esimerkiksi vertaistuki. Voimaantuminen kollektiiviseen yhteiskunnalliseen toimintaan kuuluu olennaisena järjestökoulutuksen tavoittelemaan emansipaatioon. Vapaaehtoisia kouluttavat järjestöt myös usein odottavat, että saatuja taitoja hyödynnetään yhteiseksi hyväksi. Elinikäistä oppimista tukevissa yhdistyksissä ja järjestöissä oppimista ja sen avulla voimaantumista tukevat muun muassa yhteisöllisyys ja ihmissuhteet, aatteellisuus sekä vaikuttamisen mahdollisuus niin omaan organisaatioon kuin ulkoiseen maailmaankin (Hughey, Peterson, Lowe \& Oprescu 2007; Fields 2005).

\section{UUDISTUVA OPPIMINEN HAASTAA OPPIJAA}

Agendan tavoite eriarvoisuuden vähentämiseksi kattaa niin sosiaalisia, poliittisia kuin taloudellisia ulottuvuuksia. Se esiintyi kurssien sisällöissä esteettömän toimintaympäristön kaupunkisuunnitteluna ja palveluiden saatavuutena, kuten esteettöminä kuunteluolosuhteina, akustiikkana sekä tekstitys- ja tekstiviestipalveluiden saavutettavuutena. Tavoitteeseen kytkeytyivät myös pakolaisten haavoittuva asema ja maahanmuuttajien kotouttamista tukevat ystävätoiminnan kurssit, jotka tavoittelivat kuvauksissaan sosiaalisten suhteiden ylläpitoa ja tähtäsivät kokemukselliseen toimintaan. Ystävätoiminnan kurssien tavoite oli antaa taitoja kulttuurisensitiiviseen kohtaamiseen sekä kannustaa maahanmuuttajaperheitä osallistumaan ja viettämään aikaa muiden perheiden kanssa. Yhdessäolon toivottiin lisäävän osallistujien hyvinvointia ja toimijuutta esimerkiksi vahvistamalla heidän suomen kielen taitoaan sekä antavan paikan dialogille ja yhteistyölle. Osallistujille tämä tarkoittaisi toteutuessaan vuorovaikutuksellista ja transformatiivista oppimista kulttuureista, kielestä, perinteistä ja luonnosta.

Eriarvoisuuden vähentäminen edistää samalla agendan tavoitetta rauhan ja oikeudenmukaisuuden ylläpitämisestä. Tavoite näkyi aineistossa muutamina kursseina, joiden suunnitelmissa keskityttiin esimerkiksi ilmiöoppimisen kautta globaaleihin ongelmiin ja valtarakenteisiin, jotka koettelevat kestävän kehityksen tavoitteiden toteutumista. Osaamistavoitteissa keskityttiin oppimaan "perustietoja ja käsitteitä luonnonvarojen riittävyydestä sekä ns. viheliäisistä ongelmista" ja "hahmottamaan näihin kysymyksiin erilaisia näkökulmia ja ratkaisuja".

Kurssit, joilla tunnistetaan ja tehdään näkyviksi monimuotoisia jännitteitä, kertovat osallistujille siitä, että tulevaisuuteen voi vaikuttaa (Dufva 2020). Ne auttavat löytämään asioiden ja ilmiöiden välisiä riippuvuussuhteita, kun kestävyysajattelua tuetaan laajemmassa kontekstissa. Samalla kurssit vahvistavat transformaatiota ja mahdollisesti muutokseen tähtäävää voimaannuttavaa emansipaatiota, kun järjestön ja yhdistyksen mahdollistama yhteisöllisyys ja yhteinen vaikuttaminen nousevat esiin ( $\mathrm{mm}$. Hughey ym. 2007). 


\section{KANSALAISJÄRJESTÖT KESTÄVÄÄ SIVISTYSTYÖTÄ EDISTÄMÄSSÄ}

Kansalaisjärjestöt toimivat tavoitteellisesti aktiivisen kansalaisen osallistajina, toimijuuden vahvistajina, hyvän ekologisen elämän havainnollistajina ja elinikäisen oppimisen paikkoina. Ne haluavat edistää kestävää elämää, sillä esimerkiksi ympäristökuormituksen vähentäminen näyttäytyy tulevaisuudessa kasvavana osana niiden toimintaa ja osaamistarpeita. Vuoden 2018 osaamistarvekyselyssä viidennes vastaajista nimesi kestävän elämän yhdistyksen lähitulevaisuuden osaamistarpeeksi, kun vuonna 2020 näin ajatteli jo reilu kolmannes vastaajista (Osaamistarvekysely 2020). Ekososiaalisen sivistyksen kaltaiset käsitteet ovat kuitenkin aineistomme mukaan järjestöissä vieraita. Järjestöjen edustajat kokevat sivistyksen olevan "osaamisen yläpuolella” ja asiana liian suuri järjestökoulutuksen arkeen. Järjestötoiminnan aatteellisuus on kuitenkin oppimista tukeva ja sen merkityksellisyyttä lisäävä tekijä. Se on lähteenä myös järjestötoiminnassa sivistymiselle, kyvylle ja tahdolle käyttää opittua yhteiseksi hyväksi. Sivistyminen on vahvasti läsnä järjestöjen arjessa, ja se on myös vaivihkaista, kun toiminnan piirissä olevia halutaan osallistaa ja heidän solidaarisuudentajuaan ja vaikuttamistaitojaan vahvistaa (vrt. Niemelä 2011).

Tiedon jakamisen, oppimisen ja toiminnan keskinäisen suhteen haasteellisuus nousi esille kysely- ja ryhmähaastatteluaineistossamme. Kun vastaajia pyydettiin arvioimaan, missä järjestyksessä koulutuksessa painotetaan tietoja ja taitoja, eettisiä valintoja ja yhteiskunnallista osallistumista, yli kaksi kolmannesta valitsi ensisijaiseksi painopisteeksi tiedot ja taidot. Lyhytkursseilla korostuu erityisesti tietoisuuden kasvattaminen. Niillä annetaan usein mukaan koulutusmateriaalia, jonka avulla osallistuja voi jatkaa opiskelua kurssin jälkeen. Tiedon jakamisessa ollaan kuitenkin varovaisia. Esimerkiksi ympäristövalintoja koskevaa tietoa saatetaan jakaa useasta näkökulmasta, koska kaihdetaan leimautumista ympäristöaktivisteiksi. Yksilö on tällöin vapaa tekemään eettisiä valintoja arjessaan, mutta häntä ei suoraan ohjata tähän.
Vasta toissijainen suunnitelmiin kirjattu tavoite oli oppiminen aineistoon ja havaintoihin perustuen. Osallistujat oppivat järjestötoimijoiden mielestä enemmän silloin, jos kestävyys on läpileikkaava teema järjestön arvoissa ja jäsenet pääsevät soveltamaan oppimaansa käytännössä - eli jos järjestö mahdollistaa voimauttavan emansipaation. Aineiston kurssien tavoitteissa näkyikin oppimista, joka rakentaa kestävää elämää ja siihen liittyvää transformaatiota. Erityisen hyvin analysoimamme kurssit vastasivat esimerkiksi ymmärrykseen luonnon kantokyvystä ja hiilijalanjäljen pienentämisestä vahvistamalla tietoutta kestävästä kulutuksesta ja tukemalla ruokatalouden kestäviä valintoja. Vahvana hyvinvointia lisäävänä asiana esiintyi sosiaaliturvatietouden jakaminen.

Tuloksia tarkasteltaessa on toki huomioitava, että käytettävissämme ollut Sivisverkon aineisto rajoittui saatavilla olleisiin suunnitelmakuvauksiin. Siksi sen merkitsemisen ja luokittelun avulla ei esimerkiksi päästy kiinni siihen, miten kurssit todellisuudessa toteutuivat tai siihen, tapahtuiko kurssitilanteissa kestävään elämään liittyvää oppimista, jota opintoihin ei ollut suunniteltu.

Vuonna 2018 Opintokeskus Siviksen yli 5000 opintojaksojen kurssiohjelmista vain noin seitsemään prosenttiin oli kirjattu kestävää kehitystä. Tulostemme perusteella vapaaseen sivistystyöhön tarvitaankin lisää kestävän kehityksen opetusta. Tilanne on kuitenkin oletettavasti parantunut vuodesta 2018. Suomen sosiaali ja terveys ry (SOSTE) toteutti vuonna 2020 järjestöbarometrin, jonka mukaan hieman yli kaksi kolmesta sosiaali- ja terveysjärjestöistä ilmoitti tehneensä tai toteuttavansa kuluvan vuoden aikana ilmastonmuutoksen torjumiseen tähtäävää toimintaa. Harva toimi kuitenkaan kohdentuu suoraan jäsenistön tietoisuuden lisäämiseen tai seurauksiin sopeutumiseen, vaan muutokset näkyvät järjestöjen toimintakäytännöissä, kuten digitaalisen postituksen ja tiedottamisen käyttöön ottamisena. (Peltosalmi ym. 2020.) Tämä ilmeni myös ryhmähaastatteluaineistossamme. Kestävistä valinnoista järjestökoulutuksen arjessa "tehdään harvoin numeroa" jäsenille. 
Aiemmassa tutkimuksessa on osoitettu, että järjestöt käyttävät opetuksessaan Agenda 2030 -toimenpideohjelman tapaisia kansainvälisiä hankkeita kehittääkseen ja linkittääkseen toimintaansa suurempiin kokonaisuuksiin (Henriksson 2017). Järjestötoiminnassa pystytään avaamaan kestävän elämän monitahoisuutta: osallistujat huomaavat asioiden, tekojen ja tapahtumien väliset yhteydet, niiden muodostamat laajemmat kokonaisuudet ja omat mahdollisuutensa vaikuttaa ympäristöön.

Aineistomme perusteella kursseihin suunnitellut tavoitteet näyttivät tukevan kestävän elämän oivaltamista ja valintojen vaikuttavuuden hahmottamista eli transformaatiota. Havaintojemme pohjalta järjestöjen on kuitenkin vaikeaa tarttua siihen, kantaako ajattelussa tapahtunut muutos toimintaan. Haastatteluissa syiksi mainittiin seurannan ja ohjaamisen työkalujen puute sekä tiukasti käytäntöön sidotun koulutuksen ohut yhteys käsitykseen sivistyksestä "osaamista suurempana asiana" ja sen yhteydestä kestävään elämään. Onkin syytä pohtia, missä sivistyminen näkyy: ajatuksissa, valinnoissa vai teoissa? Entä miten merkityksellisiä oppimisprosesseja järjestöt pystyvät tulevaisuudessa mahdollistamaan, kun kurssit lyhenevät lyhenemistään? Osallistumisen tulee tarjota sellaisia kokemuksia voimaantumisesta ja solidaarisuudesta, jotka mahdollistavat sivistymisen.

Ne kansalaisjärjestöt, joiden toimintaa ja koulutuksia ohjaa kestävä elämä, näyttävät esimerkkiä siinä, mitä kestävän kehityksen edistäminen järjestötoiminnassa ja koulutussisällöissä merkitsee.
Se vaatii tavoitteiden ja arvojen auki kirjoittamista sekä niiden näkymistä niin koulutuksessa kuin muussa toiminnassa. Ne vahvistavat myös yksilön transformaatiota ja emansipaatiota, siis oppimista kestävään elämään.

Vapaan sivistystyön toimijoiden tulisi hahmottaa paikkansa kestävän elämän edistäjinä, jolloin toiminta ja koulutus pedagogisine ratkaisuineen sitoutetaan siihen esimerkiksi sertifioinnilla. Käytännössä järjestöt tarvitsevat monipuolisia lähestymistapoja voidakseen koulutuksillaan tukea kestävän elämän tavoitteita sekä keskustelua siitä, mikä kaikki niissä edistää kestävää sivistystä. Tietoa on tarjottava ja siitä on viestittävä niin, että se mahdollistaa laajentuvan oppimisen ja kestävyyttä koskevien ajattelutapojen muutoksen.

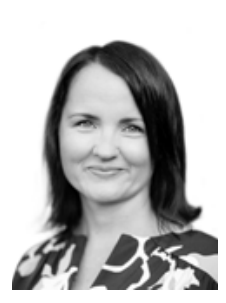

KRISTIINA HANNUKAINEN

$\mathrm{FT}$, asiantuntija

Opintokeskus Sivis

(D) https:// orcid.org/0000-00030994-5126

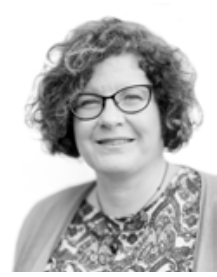

MARION FIELDS

VTT, asiantuntija

Opintokeskus Sivis

(D) https:// orcid.org/0000-00031790-8173

\section{LÄHTEET.}

Dufva, M. (2020). Megatrendit 2020. Sitran selvityksiä 162. Helsinki: Sitra.

Eskola, J. \& Suoranta, J. (2000). Johdatus laadulliseen tutkimukseen. Tampere: Vastapaino.

Euroopan komissio. (2016). Ehdotus uudeksi kehityspolitiikkaa koskevaksi eurooppalaiseksi konsensukseksi. Meidän maailmamme, meidän ihmisarvomme, meidän tulevaisuutemme. Strasbourg, 22.11.2016 COM (2016) 740 final.

Euroopan aikuiskoulutusjärjestö EAEA. (2016). Aikuiskoulutuksella tulevaisuuteen. Manifesti.
Euroopan aikuiskoulutusjärjestö, Kansanvalistusseura \& Vapaa sivistystyö ry.

Fields, M. (2005). To Educate, Empower or Economise? Lifelong Learning in Civil Society Organisations. Turku: Koulutussosiologian tutkimuskeskus. Turun yliopisto.

Foster, R., Salonen, A. \& Keto, S. (2019). Kestävyystietoinen elämänorientaatio pedagogisena päämääränä. Teoksessa T. Autio, L. Hakala \& T. Kujala (toim.) Siirtymiä ja ajan merkkejä koulutuksessa: Opetussuunnitelmatutkimuksen näkökulmia. Tampere: Tampere University Press, 121-143. 
Henriksson, H. (2017). Kansalaisjärjestöt ja valtavirtaistuvan globaalikasvatuksen episteeminen hallinta. Kasvatus, 48(5), 429-440.

Hughey, J., Peterson, N. A., Lowe, J. B. \& Oprescu, F. (2007). Empowerment and Sense of Community: Clarifying Their Relationship in Community Organizations. Health Education \& Behavior, 35(5), 651-663.

Global Sustainable Development Report. (2019). The Future is Now - Science for Achieving Sustainable Development. New York: United Nations. https://sustainabledevelopment.un.org/ content/documents/24797GSDR_report_2019.pdf (18.11.2020).

Joutsenvirta, M. \& Salonen, A. O. (2020). Sivistys vaurautena. Radikaalisti mutta lempeästi kohti kestävää yhteiskuntaa. Helsinki: Basam Books.

Kestävyyspaneeli. (2020). Kuusi polkua kestävyyteen. Evästykset systeemisen kestävyysmurroksen edistämiseksi Suomessa. Kestävyyspaneelin julkaisuja $1 / 2020$.

Laininen, E. (2018). Transformatiivinen oppiminen ekososiaalisen sivistymisen näkökulmasta. Ammattikasvatuksen aikakauskirja, 20(5), 16-38.

Laki vapaasta sivistystyöstä. 632/1998.
Lansbury Hall, N. \& Taplin, R. (2007). Revolution or inchby inch? Campaign approaches on climate change by environmental groups. Environmentalist 27, 95-107.

Mezirow, J. (1997). Transformative Learning: Theory to Practice. New Directions for Adult and Continuing Education, 27, 5-12.

Niemelä, S. (2011). Sivistyminen. Sivistystarve, -pedagogiikka ja -politiikka pohjoismaisessa kansansivistystraditiossa. Helsinki: Kansanvalistusseura \& Snellman-instituutti.

Osaamistarvekysely 2020. Järjestöjen osaamistarpeet ja koulutuksen trendit. Opintokeskus Sivis.

Peltosalmi J., Eronen A., Haikari J., Laukkarinen M., Litmanen T., Londén P. \& Ruuskanen P. (2020). Järjestöbarometri 2020. SOSTE Suomen sosiaali- ja terveys ry. Helsinki.

Taylor, E. W. (2008). Transformative Learning. New Directions for Adult and Continuing Education, 119, 5-15. https://doi. org/10.1002/ace.301 (16.11.2020).

The United Nations Statistics Division (UNSD). (2017). Revised list of global Sustainable Development Goal indicators. https://unstats.un.org/sdgs/indicators/ Official\%20Revised\%20List\%20of\%20global\%20 SDG\%20indicators.pdf (10.11.2020). 